\title{
Conditioning stochastic properties of daily precipitation on indices of atmospheric circulation
}

\author{
Gerard Kiely ${ }^{1}$, John D Albertson ${ }^{2}$, Marc B Parlange ${ }^{3}$ and Richard W Katz ${ }^{4}$ \\ ${ }^{1}$ University College Cork, Ireland \\ ${ }^{2}$ University of Virginia, Charlottesville, Virginia, USA \\ ${ }^{3}$ The Johns Hopkins University, Baltimore, Maryland, USA \\ ${ }^{4}$ National Center for Atmospheric Research, Boulder, Colorado, USA (The National Center \\ for Atmospheric Research is sponsored by the National Science Foundation)
}

Time series of daily precipitation, at Valentia, Ireland, are examined using conditioned chaindependent processes. The conditioning is carried out using two different indices of large-scale atmospheric circulation. The first conditioning index relates to mean monthly sea level pressure (SLP), conditioned as either above or below the historic monthly mean. The second conditioning index is based on the geostrophic wind direction (GWD), conditioned as being inside or outside the historic storm quadrant for the month. For each conditioning index, there are two conditioned daily models and they differ in the parameters that relate to both occurrence and intensity and therefore to changes in the distribution of monthly total precipitation. The results of conditioning the daily precipitation on SLP are compared with conditioning on GWD. The GWD conditioned model gave similar results to the SLP conditioned model for the wetter months, but performed poorly for the summer season. Combining the two SLP conditioned daily models into an induced model, which is a mixture of the two chain dependent processes, produces a variance for monthly total precipitation that is closer to the observed value than the unconditioned chain-dependent model.

\section{Introduction}

The relationship between precipitation and large-scale measures of atmospheric circulation has received much attention in recent years (e.g. Bardossy \& Caspary, 1990; Bardossy \& Plate, 1992; Hughes et al., 1993; Woolhiser et al., 1993; Katz \& Parlange, 1993). Some of the interest relates to quantifying the possible change in atmospheric circulation within the past two decades, with associated changes to precipitation occurrence and intensity (Bardossy \& Caspary, 1990; Kiely et al., 1998). Other interest is due to the fact that General Circulation Models (GCMs) can provide sea level pressure fields for future climate conditions (e.g. under increased greenhouse gas concentrations). However, because of their coarse resolution (e.g. there might be only one grid point for Ireland), they cannot adequately represent local precipitation. A stochastic precipitation model, conditioned on a suitable atmospheric circulation parameter/index, could be used in simulating monthly precipitation distributions. A comparison of unconditioned chain-dependent models for daily precipitation with conditioned models showed the latter to be an important improvement for the modelled stochastic precipitation process (e.g. Katz \& Parlange, 1993).
It is common in hydrology to fit stochastic models to the full time series of precipitation amounts. However, precipitation amount lends itself to splitting (or conditioning) the time series into two (e.g. the part of the series of lower precipitation amounts associated with high sea level pressure and the other part of the time series of higher precipitation amounts associated with low sea level pressure). A suitable atmospheric circulation index on which to condition precipitation could include among others: sea level pressure (SLP), geostrophic wind direction (GWD), sea surface temperature (SST) and a Lamb (1950) type wind direction classification index. Much use has been made of the 'El Niño' or Southern Oscillation phenomenon as a conditioning index in regions known to be sensitive. The North Atlantic Oscillation has also been used as a circulation index (Hurrell, 1995). Katz \& Parlange (1993), using precipitation data for California, developed two conditioned daily models, which differ in terms of the parameters of the occurrence process and the intensity process. Each of these daily effects contributes to changes in the distribution of monthly total precipitation associated with the SLP circulation index. They showed how a daily conditioned model could be used to induce an improved monthly model. The induced model is a combination of both conditioned models 
with different parameters. The induced monthly means are identical to the unconditional model means, but the induced model produces a variance for total monthly precipitation that is different to the unconditional model variances and is closer to the observed variances.

In this paper we use a daily precipitation set and a daily SLP set, each of length 54 years (1940-1993), from Valentia in south-west Ireland. The location of the site is shown in Figure 1. We also use a daily wind direction data set (at $850 \mathrm{mb}$ ) of length 35 years (1952-1986). We condition precipitation data by partitioning the time series of precipitation into two sets. In the case of SLP, we identify the mean monthly sea level pressure for each month. For each month (say January) we then partition the time series into a sub-series associated with Januarys above the mean January sea level pressure, and a second sub-series associated with Januarys below the mean January sea level pressure. Obviously, the Januarys associated with the 'lows' produce higher monthly mean precipitation. We develop two daily conditioned models: one associated with above mean SLP and the other associated with below mean SLP. This 'conditioning' process is repeated for each of the 12 months. Following Katz \& Parlange (1993) we aggregate the two daily conditioned models to two monthly conditioned models. We then use a combination of both conditioned models to develop an induced monthly model. In the case of Geostrophic Wind Direction, we identify a 'storm window' for each month (e.g. the $180-270^{\circ}$ quadrant) and partition the precipitation into a sub-series of those Januarys associated with a monthly mean wind direction in the 'storm window' and a second sub-series for those Januarys outside the 'window'. As with SLP we develop two conditioned daily models, and aggregate these to two conditioned monthly models and then combine both into an induced monthly model.

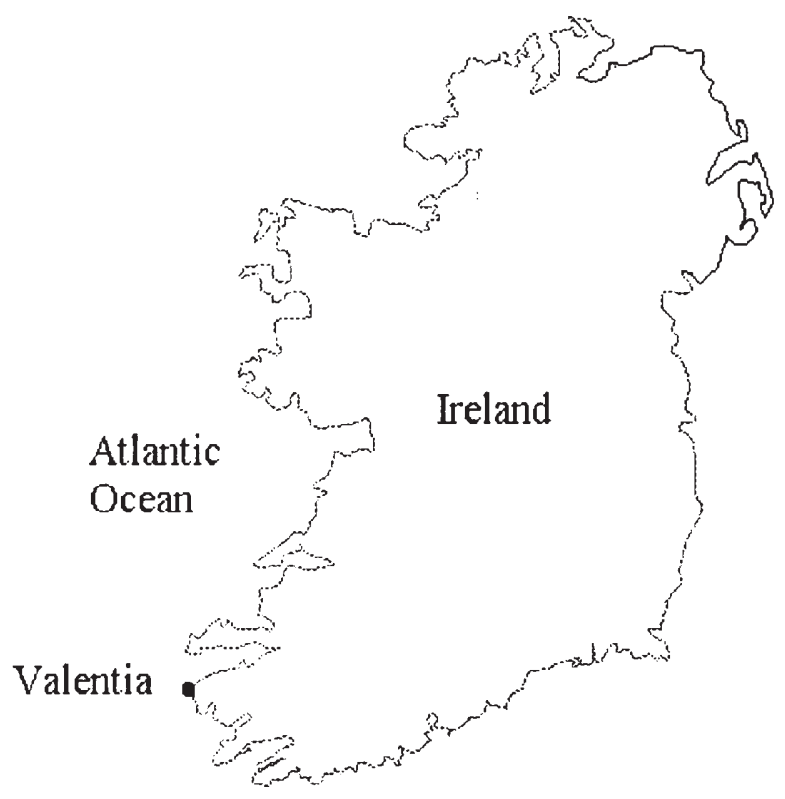

Figure 1. Location map of Valentia, south-west Ireland.

\section{Atmospheric circulation and monthly precipitation}

\section{I. Sea level pressure index}

Cayan \& Peterson (1989) and Weare \& Hoeschele (1983) found, for California, that patterns in atmospheric circulation (as exemplified by SLP) do have a strong effect on precipitation over much of the state, during the wet months, October to May. At Valentia, Ireland, precipitation is spread more evenly throughout the year, with a mean varying from about $70-90 \mathrm{~mm}$ per month in April, May, June and July to $100-160 \mathrm{~mm}$ per month for all other months. So, because of significant precipitation in all months, we would expect that a model of the precipitation process conditioned on SLP would be valid throughout the year, and not just the winter months.

The site of this study is on the south-west coast of Ireland, where the sea level pressure data is at the same site $\left(51^{\circ} 52^{\prime} \mathrm{N}, 10^{\circ} 23^{\prime} \mathrm{W}\right)$ as the precipitation measurements. We assume stationarity from day to day within the month, non-stationarity from month to month throughout the year and stationarity from year to year. So we allow for seasonal variations while assuming that the statistical structure is stationary within each month and does not vary from year to year. The mean monthly SLP is used to construct an index of atmospheric circulation. By definition we do not allow the index to vary within the month. The 12 months of the year are used, and each month has a different mean monthly SLP. The index is defined as:

$$
\begin{aligned}
& I=0 \text { if monthly SLP }<\text { mean } \\
& I=1 \text { if monthly SLP }>\text { mean }
\end{aligned}
$$

The mean here is the historic mean for the subject month over the long term sample of the pressure record, in this case 54 years (1940-1993). For January, the value is $1012.5 \mathrm{mb}$ and for July it is $1017.0 \mathrm{mb}$, as seen in Table 1.

Table 1. Mean monthly SLPs (1940-1993) and mean monthly active storm windows (1952-1986) at Valentia

\begin{tabular}{lll}
\hline \hline Month & $\begin{array}{l}\text { Mean } \\
\text { monthly } \\
\text { SLP } \\
(\mathrm{mb})\end{array}$ & $\begin{array}{l}\text { Mean } \\
\text { monthly } \\
\text { active storm window } \\
\text { degrees }\end{array}$ \\
\hline January & 1012.5 & $220-280$ \\
February & 1013.5 & $190-280$ \\
March & 1013.3 & $210-290$ \\
April & 1015.5 & $140-310$ \\
May & 1015.0 & $213.5-275$ \\
June & 1016.8 & $247.5-290$ \\
July & 1017.0 & $262.5-295$ \\
August & 1015.2 & $248.7-282$ \\
September & 1014.8 & $237.5-266$ \\
October & 1013.4 & $228-262$ \\
November & 1012.7 & $241-285$ \\
December & 1012.5 & $235-280$ \\
\hline \hline
\end{tabular}




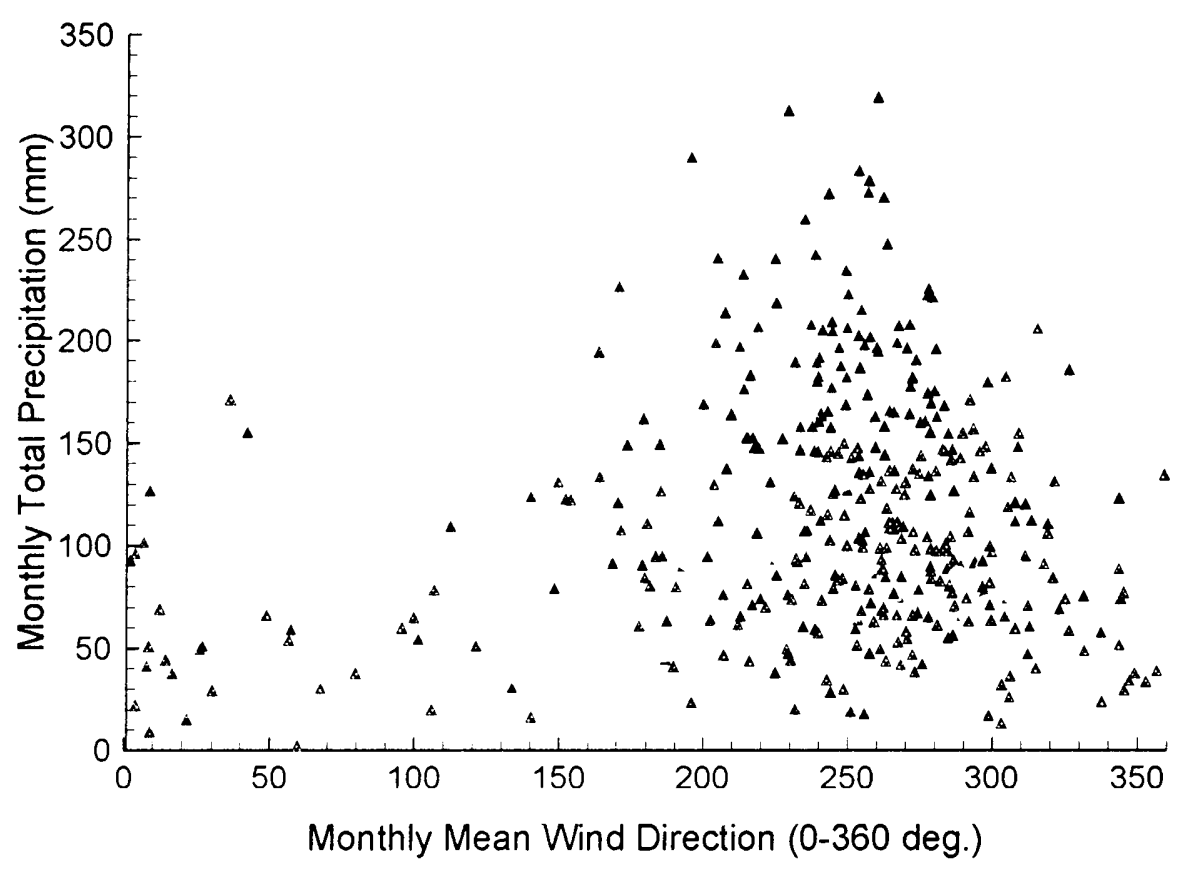

Figure 2. Observed monthly mean wind direction and monthly total precipitation.

\subsection{Geostrophic wind direction index}

Using the Lamb (1950) synoptic classification, for several stations in Ireland, Houghton \& O'Cinneide (1976) categorised rainfall for magnitudes (both annual totals and daily means) for 1971-1972. The seven classifications used are anticyclonic, cyclonic, westerly, north-westerly, northerly, easterly and southerly. For Valentia, they identify that annual precipitation is partitioned approximately as $30 \%$ to cyclonic, $30 \%$ to westerly and about $10 \%$ to southerlies. Westerlies contribute most precipitation in the autumn, while the cyclonics contribute a relatively uniform amount throughout the year and also a relatively uniform amount throughout the island of Ireland. Precipitation bearing westerlies have a distinguishing precipitation gradient from west to east across the island. Sweeney (1985) and Sweeney \& O'Hare (1992) examined the categorises of Irish precipitation using an extended (27 categories) Lamb classification system. They found that cyclonic south-westerlies are the most prolific precipitation synoptic types for Ireland as a whole. It is clear from Sweeney \& O'Hare (1992) that precipitation for Valentia is predominantly from the $180-270^{\circ}$ quadrant (i.e. from the south-west). Obviously, this 'storm window' will vary somewhat for each month of the year, as shown in Table 1.

In conditioning precipitation with a wind direction index, it is possible to consider at least two options: the geostrophic wind direction (GWD) or the Lamb (1950) type classification. For this study we use the geostrophic wind direction (at $850 \mathrm{mb}$ ) and compose an index. We choose GWD partly because there is interest in a perceived circulation change (since the 1970s) towards more frequent westerlies (rain bearing to Ireland) in Western Europe (as noted by Bardossy \& Caspary, 1990, for December and January) and as such a change is readily studied in the GWD context. Figure 2 shows the monthly mean wind direction (versus the monthly total precipitation) at Valentia, and the concentration is seen to be centred about $250^{\circ}$ or west-south-west. The wind direction from the $850 \mathrm{mb}$ level was chosen as it was considered to be above the influence of local orography, as hills in the region are no higher than about $300 \mathrm{~m}$. Wind direction data for the 35 year period (1952-1986) on a six hour time step were used. For the 35 Januarys, we compute the 35 monthly mean wind directions. For the same time periods we compute the monthly precipitation. When the precipitation is plotted against the wind direction, we then visually identify an 'active storm quadrant', for each month, containing approximately half of the events with the largest amount of precipitation. For January we identify the 'storm window' as $220-280^{\circ}$ and for July as $262.5-295^{\circ}$. Table 1 identifies the 'storm window' for all 12 months. For wind direction index notation (consistent with SLP) we adopt:

$$
\begin{gathered}
\mathrm{I}+0 \text { if monthly GWD is within } \\
\text { the active storm window } \\
\mathrm{I}+1 \text { if monthly GWD is outside } \\
\text { the active storm window }
\end{gathered}
$$

The GWD index is somewhat 'subjective' and so, poor selection of the 'active storm window' can lead to varying results. By comparison, the SLP index is more objective, and simpler to compute. As with the SLP index, on the assumption of stationarity, we do not permit the GWD index to vary within the month. 


\section{Summary statistics for unconditioned and conditioned monthly distributions}

Using SLP conditioning to partition the data from 1940-1993, the observed monthly standard deviations of the unconditioned and conditioned distributions for the total precipitation for each of the 12 months at Valentia are summarised in Table 2. Similarly, Table 3 is a summary based on conditioning with GWD for the period available, 1952-1986.

Figure 3(a) shows the mean monthly precipitation for the unconditioned and two conditioned distributions based on SLP. It shows that:

(a) The conditioned mean ( $I=0$, low pressure) is always greater than the unconditioned mean.

(b) The conditioned mean $(I=1)$ is always less than the unconditioned mean.

Figure 3(b) shows the mean monthly precipitation for the unconditioned and two conditioned distributions based on GWD. It shows that:

(a) The conditioned mean ('within the storm window', $I=0$ ) is higher than the unconditioned mean for all months except June.

Table 2. Standard deviation of monthly total precipitation from unconditioned, conditioned and induced models for daily precipitation at Valentia, 1940-1993, conditioned on SLP. Observations are in parentheses

\begin{tabular}{|c|c|c|c|c|}
\hline $\begin{array}{r}\text { Month } \\
\text { und }\end{array}$ & $\begin{array}{l}\text { Standard } \\
\text { deviation, } \\
\text { conditioned } \\
(\mathrm{mm})\end{array}$ & $\begin{array}{l}\text { Standard } \\
\text { deviation, } \\
\text { induced } \\
(\mathrm{mm})\end{array}$ & $\begin{array}{c}\text { Standard } \\
\text { deviation, } \\
\text { conditioned } \\
I=1 \\
(\mathrm{~mm})\end{array}$ & $\begin{array}{c}\text { Standard } \\
\text { deviation, } \\
\text { conditioned } \\
I=0 \\
(\mathrm{~mm})\end{array}$ \\
\hline January & $\begin{array}{c}44.9 \\
(57.4)\end{array}$ & $\begin{array}{c}53.2 \\
(57.4)\end{array}$ & $\begin{array}{c}45.8 \\
(47.5)\end{array}$ & $\begin{array}{c}42.0 \\
(51.4)\end{array}$ \\
\hline February & $\begin{array}{c}37.4 \\
(58.7)\end{array}$ & $\begin{array}{c}50.6 \\
(58.7)\end{array}$ & $\begin{array}{c}42.4 \\
(44.8)\end{array}$ & $\begin{array}{c}30.0 \\
(48.7)\end{array}$ \\
\hline March & $\begin{array}{c}38.3 \\
(59.1)\end{array}$ & $\begin{array}{c}50.9 \\
(59.1)\end{array}$ & $\begin{array}{c}42.0 \\
(52.2)\end{array}$ & $\begin{array}{c}31.1 \\
(43.2)\end{array}$ \\
\hline April & $\begin{array}{c}30.0 \\
(34.9)\end{array}$ & $\begin{array}{c}34.3 \\
(34.9)\end{array}$ & $\begin{array}{c}32.2 \\
(30.3)\end{array}$ & $\begin{array}{c}26.6 \\
(27.4)\end{array}$ \\
\hline May & $\begin{array}{c}31.3 \\
(42.2)\end{array}$ & $\begin{array}{c}41.3 \\
(42.2)\end{array}$ & $\begin{array}{c}35.8 \\
(34.4)\end{array}$ & $\begin{array}{c}25.8 \\
(30.8)\end{array}$ \\
\hline June & $\begin{array}{c}29.8 \\
(30.5)\end{array}$ & $\begin{array}{c}31.9 \\
(30.5)\end{array}$ & $\begin{array}{c}29.7 \\
(25.8)\end{array}$ & $\begin{array}{c}28.6 \\
(29.3)\end{array}$ \\
\hline July & $\begin{array}{c}29.8 \\
(44.2)\end{array}$ & $\begin{array}{c}38.1 \\
(44.2)\end{array}$ & $\begin{array}{c}32.7 \\
(42.9)\end{array}$ & $\begin{array}{c}25.7 \\
(31.1)\end{array}$ \\
\hline August & $\begin{array}{c}34.0 \\
(53.1)\end{array}$ & $\begin{array}{c}44.6 \\
(53.1)\end{array}$ & $\begin{array}{c}36.7 \\
(47.6)\end{array}$ & $\begin{array}{c}28.0 \\
(41.1)\end{array}$ \\
\hline September & $\begin{array}{c}41.2 \\
(57.4)\end{array}$ & $\begin{array}{c}57.6 \\
(57.4)\end{array}$ & $\begin{array}{c}47.7 \\
(41.6)\end{array}$ & $\begin{array}{c}30.6 \\
(35.7)\end{array}$ \\
\hline October & $\begin{array}{c}43.6 \\
(62.1)\end{array}$ & $\begin{array}{c}60.7 \\
(62.1)\end{array}$ & $\begin{array}{c}47.8 \\
(49.4)\end{array}$ & $\begin{array}{c}38.1 \\
(43.3)\end{array}$ \\
\hline November & $\begin{array}{c}43.9 \\
(55.2)\end{array}$ & $\begin{array}{c}51.6 \\
(55.2)\end{array}$ & $\begin{array}{c}44.6 \\
(44.8)\end{array}$ & $\begin{array}{c}41.4 \\
(49.4)\end{array}$ \\
\hline December & $\begin{array}{c}43.4 \\
(61.3)\end{array}$ & $\begin{array}{c}52.0 \\
(61.3)\end{array}$ & $\begin{array}{c}45.6 \\
(56.5)\end{array}$ & $\begin{array}{c}39.4 \\
(50.5)\end{array}$ \\
\hline
\end{tabular}

(b) The conditioned mean ('outside the storm window', $I=1$ ) is lower than the unconditioned mean for all months except June.

The differences between the two conditioned means for the SLP case are greater than the corresponding differences in the GWD case. For both SLP and GWD conditioning, the conditioned monthly standard deviations as shown in Figure 4 are always less than the unconditioned standard deviations. Since the time series record for the conditioned sets is shorter than that for the unconditioned time series, we expect the conditioned standard deviations to be less than the unconditioned. While the unconditioned mean is simply the weighted average of the two conditioned means, the unconditioned standard deviation is not the weighted average of the two conditioned standard deviations. It is the standard deviation of a mixed distribution, made up of the two conditioned distributions.

\section{Chain-dependent process model for daily precipitation}

Precipitation is modelled using the chain-dependent process (Katz, 1977a, Katz \& Parlange, 1993), which

Table 3. Standard deviation of monthly total precipitation from unconditioned, conditioned and induced models for daily precipitation at Valentia, 1952-1986, conditioned on GWD. Observations are in parentheses

\begin{tabular}{|c|c|c|c|c|}
\hline $\begin{array}{l}\text { Month } \\
\text { un }\end{array}$ & $\begin{array}{l}\text { Standard } \\
\text { deviation, } \\
\text { nconditioned } \\
(\mathrm{mm})\end{array}$ & $\begin{array}{l}\text { Standard } \\
\text { deviation, } \\
\text { induced } \\
(\mathrm{mm})\end{array}$ & $\begin{array}{c}\text { Standard } \\
\text { deviation, } \\
\text { conditioned } \\
I=1 \\
(\mathrm{~mm})\end{array}$ & $\begin{array}{c}\text { Standard } \\
\text { deviation, } \\
\text { conditioned } \\
I=0 \\
(\mathrm{~mm})\end{array}$ \\
\hline January & $\begin{array}{c}42.5 \\
(59.1)\end{array}$ & $\begin{array}{c}38.0 \\
(59.1)\end{array}$ & $\begin{array}{c}43.4 \\
(58.2)\end{array}$ & $\begin{array}{c}41.6 \\
(54.3)\end{array}$ \\
\hline February & $\begin{array}{c}37.7 \\
(59.3)\end{array}$ & $\begin{array}{c}41.3 \\
(59.3)\end{array}$ & $\begin{array}{c}39.1 \\
(52.4)\end{array}$ & $\begin{array}{c}34.0 \\
(52.6)\end{array}$ \\
\hline March & $\begin{array}{c}41.8 \\
(61.9)\end{array}$ & $\begin{array}{c}44.1 \\
(61.9)\end{array}$ & $\begin{array}{c}40.7 \\
(62.1)\end{array}$ & $\begin{array}{c}39.8 \\
(47.7)\end{array}$ \\
\hline April & $\begin{array}{c}30.4 \\
(33.8)\end{array}$ & $\begin{array}{c}33.4 \\
(33.8)\end{array}$ & $\begin{array}{c}33.1 \\
(27.9)\end{array}$ & $\begin{array}{c}25.5 \\
(23.5)\end{array}$ \\
\hline May & $\begin{array}{c}29.7 \\
(40.8)\end{array}$ & $\begin{array}{c}34.7 \\
(40.8)\end{array}$ & $\begin{array}{c}31.0 \\
(33.0)\end{array}$ & $\begin{array}{c}25.8 \\
(34.2)\end{array}$ \\
\hline June & $\begin{array}{c}29.5 \\
(26.8)\end{array}$ & $\begin{array}{c}23.8 \\
(26.8)\end{array}$ & $\begin{array}{c}28.0 \\
(32.1)\end{array}$ & $\begin{array}{c}31.0 \\
(19.5)\end{array}$ \\
\hline July & $\begin{array}{c}29.2 \\
(42.2)\end{array}$ & $\begin{array}{c}36.5 \\
(42.2)\end{array}$ & $\begin{array}{c}34.5 \\
(37.0)\end{array}$ & $\begin{array}{c}21.5 \\
(24.3)\end{array}$ \\
\hline August & $\begin{array}{c}35.7 \\
(52.9)\end{array}$ & $\begin{array}{c}29.2 \\
(52.9)\end{array}$ & $\begin{array}{c}31.4 \\
(54.2)\end{array}$ & $\begin{array}{c}39.2 \\
(53.1)\end{array}$ \\
\hline September & $\begin{array}{c}40.7 \\
(60.1)\end{array}$ & $\begin{array}{c}46.3 \\
(60.1)\end{array}$ & $\begin{array}{c}47.1 \\
(40.6)\end{array}$ & $\begin{array}{c}33.9 \\
(67.8)\end{array}$ \\
\hline October & $\begin{array}{c}41.7 \\
(60.6)\end{array}$ & $\begin{array}{c}41.1 \\
(60.6)\end{array}$ & $\begin{array}{c}42.0 \\
(65.5)\end{array}$ & $\begin{array}{c}39.4 \\
(54.4)\end{array}$ \\
\hline November & $\begin{array}{c}45.8 \\
(54.1)\end{array}$ & $\begin{array}{c}45.6 \\
(54.1)\end{array}$ & $\begin{array}{c}47.5 \\
(47.8)\end{array}$ & $\begin{array}{c}41.9 \\
(45.2)\end{array}$ \\
\hline December & $\begin{array}{cc}r & 42.8 \\
& (61.4)\end{array}$ & $\begin{array}{c}40.6 \\
(61.4)\end{array}$ & $\begin{array}{c}42.3 \\
(61.3)\end{array}$ & $\begin{array}{c}42.7 \\
(53.0)\end{array}$ \\
\hline
\end{tabular}



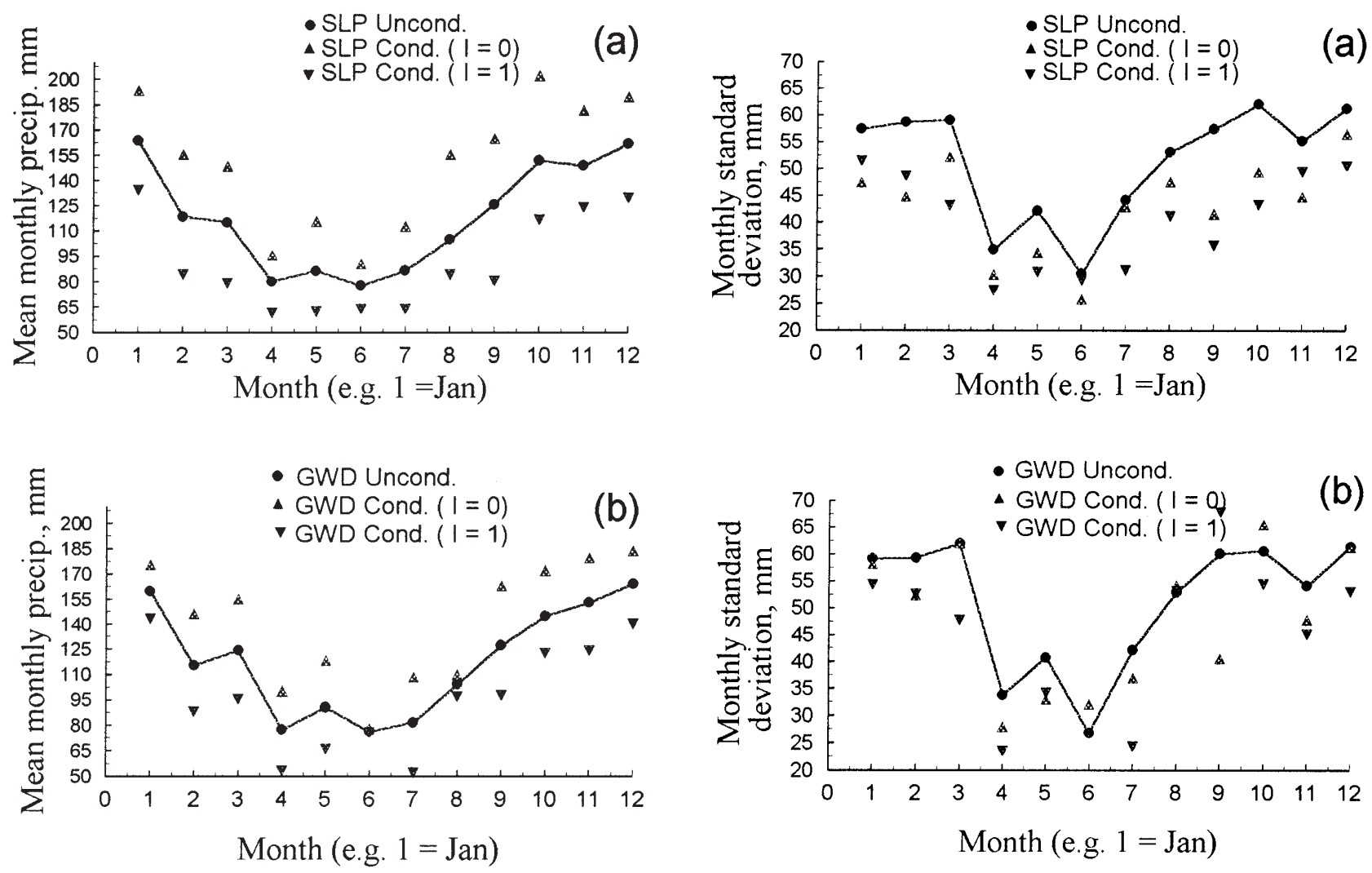

Figure 3. Observed mean monthly precipitation for the unconditioned and conditioned models for (a) sea level pressure (SLP) and (b) geostrophic wind direction (GWD).

divides the precipitation event into a simple two component process: an occurrence process or sequence of wet and dry days, and an intensity process which defines the intensity in each wet interval.

The occurrence process $\left\{U_{t}: t=1,2, \ldots\right\}$ is defined as:

$$
\begin{aligned}
& \mathrm{J}_{t}=1 \text { if day } t \text { is wet } \\
& \mathrm{J}_{t}=0 \text { otherwise }
\end{aligned}
$$

The occurrence process is assumed to constitute a two state, first order Markov-chain (Waymire \& Gupta, 1981). The stochastic model is completely characterised by the transition probabilities:

$$
P_{i j}=\operatorname{Pr}\left\{J_{t+1}=j \mid J_{t}=i\right\} \quad i, j=0,1, \ldots
$$

where $P_{i j}$ is the probability that $J_{t+1}=j$ given that $J_{t}=\mathrm{i}$. For example, $P_{01}$ is the probability of a wet day following a dry day and $P_{11}$ is the probability of a wet day following a wet day. Clearly $P_{i 0}+P_{i 1}=1$. The Markovchain is defined by the probability of a wet day, $\pi$, and the first order autocorrelation coefficient, $\rho$ (persistence parameter):

$$
\begin{aligned}
& \pi=\operatorname{Pr}\left\{J_{t}=1\right\}=P_{01} /\left[P_{01}+P_{10}\right] \\
& \rho=\operatorname{Corr}\left\{J_{t}, J_{t+1}\right\}=P_{11}-P_{01}
\end{aligned}
$$

The intensity process is represented by a series of random variables $\left\{X_{k} ; k=1,2, \ldots\right\}$ where $X_{k}$ is the amount of precipitation on the $k$ 'th wet day. The distribution is assumed to have a mean $\mu$ and variance $\sigma^{2}$. Daily pre-

Figure 4. Observed standard deviation of monthly precipitation for the unconditioned and conditioned models for (a) sea level pressure (SLP) and (b) geostrophic wind direction (GWD).

cipitation distributions are positively skewed, so to 'normalise' we use a power transform function (after Katz \& Parlange, 1993):

$$
X_{k}^{*}=X_{k}^{p}, 0<p<1
$$

where $X_{k}^{*}$ has a normal distribution with transformed mean $\mu^{*}$ and transformed variance $\left(\sigma^{*}\right)^{2}$. Typically, the mean and the variance $\left(\mu\right.$ and $\left.\sigma^{2}\right)$ of the untransformed intensities are functions (depending on the power transform parameter $p$ ) of both the transformed mean and variance $\left(\mu^{*}\right.$ and $\left.\left(\sigma^{*}\right)^{2}\right)$. The power transform parameter (typically $1 / 8,1 / 4$, or $1 / 2$ ) is obtained by minimising the Hinkley statistic for the normalised, $X^{*}$ distribution:

$$
d_{p}=\frac{\text { mean }- \text { median }}{\text { standard deviation }}
$$

Here, the mean, median and standard deviation are computed for the sample of the $p$ th power transformed data (equation (6)). When we compare the values computed using equation (7), for the trial values of $p(1 / 8,1 / 4$, or $1 / 2)$, we select the $p$ that minimises the degree of skewness, (i.e. $d_{\mathrm{p}} \approx 0$ ). The transformed parameters, $\mu^{*}$ and $\sigma^{*}$, are then estimated as sample mean and standard deviation of the transformed intensities, $X_{k}^{*}$

\section{Daily model fitting with the SLP index}

For the daily precipitation model, the chain-dependent process is fit to three different time series sets of daily precipitation amounts (for each month of the year): 
(a) the unconditioned model for all (54) years,

(b) the conditioned model for low pressure months $(I=0)$, and

(c) the conditioned model for high pressure months $(I=1)$.

All three models are assumed stationary within the month, and the power transform parameter is constrained to remain the same for all three models within the month (Katz \& Parlange, 1993).

Table A1 in the Appendix shows the estimated parameters for the unconditioned and two conditioned models for daily precipitation, for each of the 12 months at Valentia. For the unconditioned model the estimated probability of a wet day, p, ranges from 0.606 in May to 0.813 in December, verifying the seasonal differences. The unconditioned daily mean intensity ranges from 4.1 $\mathrm{mm}$ in June to $6.74 \mathrm{~mm}$ in October. It is found that:

(a) For the conditioned model (low pressure months), the probability of a wet day, $\pi$, is always higher than the unconditioned model, although no such clear trends are apparent for the persistence parameter, $\rho$.

(b) For the conditioned model (high pressure months), the probability of a wet day, $\pi$, is always lower than the unconditioned model, and again no such clear trends are apparent for the persistence parameter, $\rho$.

Figure 5 is a plot of the seasonal variation of daily statistics: the mean intensity, standard deviation, the occurrence (or probability of a wet day) and the persistence parameter for the unconditioned and two SLP conditioned models. The daily mean is very sensitive to SLP conditioning as evidenced by the difference between the two conditioned models of $56 \%$ and $58 \%$ for the months of February and September respectively. The same trend, though less dramatic, holds for the standard deviation of daily precipitation. For both the mean and standard deviation the least pronounced differences are in June. Figure 5(c) shows that the daily occurrences (probability of a wet day) are very different for the unconditioned and conditioned models with differences as high as $42 \%$ for August and $36 \%$ for May, but as low as $11 \%$ for December. The power transform parameter was found to alternate between $1 \frac{1}{8}$ and $1 / 4$. In general, the untransformed mean depends on both the transformed mean and the variance. Likewise, the untransformed variance depends on both the transformed mean and the variance. Table A1 in the Appendix shows that the transformed daily mean increases (or decreases) when the untransformed mean increases (or decreases). For the exact formulae in the simpler case of the square root transformation see Katz \& Garrido (1984).

\section{Daily model fitting with GWD index}

As with SLP, the chain-dependent process, using GWD conditioning, is fit to three different time series of daily precipitation amounts:
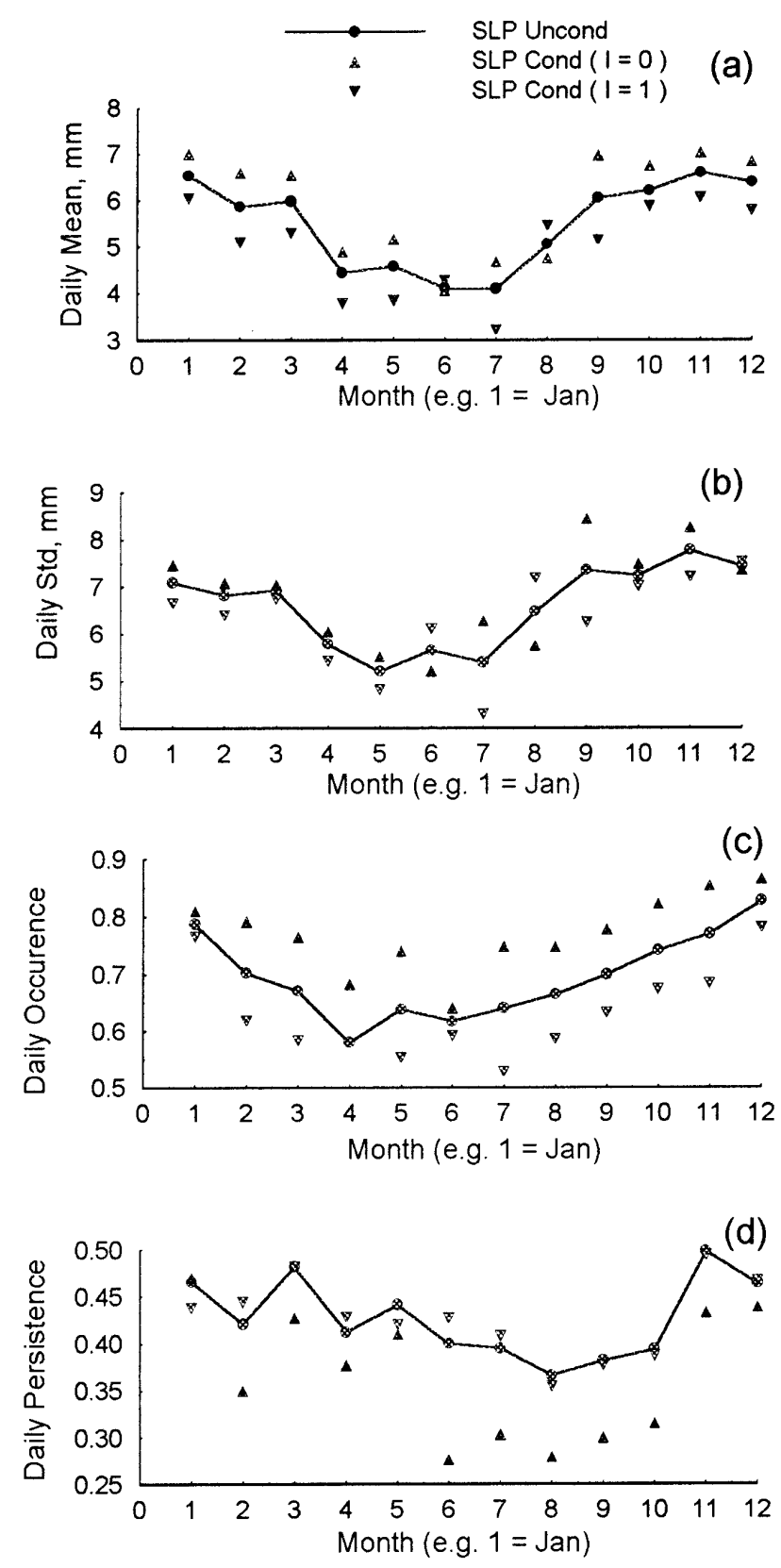

Figure 5. (a) Daily mean intensity, (b) standard deviation, (c) probability of wet days (only) and (d) persistence for the unconditioned and SLP conditioned models.

(a) the unconditioned model for all 35 years,

(b) the conditioned model for years with $I=0$ (months in the storm window), and

(c) the conditioned model with $I=1$.

Table A2 in the Appendix shows the estimated parameters for the unconditioned and two conditioned models for daily precipitation, for each of the 12 months at Valentia. The data set used in the GWD computations is for 35 years, as compared with the 54 years for the SLP exercise, so we expect some differences in the unconditioned model results. The daily mean intensity is sensitive to conditioning and the difference between the two conditioned models is as much as $46 \%$ for the month of July and $36 \%$ for September. 
The same trend holds for the standard deviation of daily precipitation. For both the mean and standard deviation the least differences between the two conditioned models are in April and June.

A comparison of Tables A1 and A2, for the SLP and GWD respectively, indicates that SLP indexing shows greater distinction between the two conditioned models $(I=0$ and $I=1)$ for the mean, standard deviation and probabilities of wet days, over almost the full year. The remainder of this paper therefore concentrates on the SLP models rather than on the GWD model.

Tables A1 and A2 enumerate the four parameters $(\pi, \rho$, $\left.\mu^{*}, \sigma^{*}\right)$, some or all of which may be allowed to vary with the SLP or the GWD index, to produce the best fit to the time series of daily precipitation. Using the method of maximum likelihood (e.g. Katz \& Parlange, 1993), the optimum number of parameters was found to be two, $\pi$ and $\mu^{*}$. In other words, we can at least be confident that the relative frequency of wet days as well as the mean and standard deviation of the distribution of daily intensity (recall from section 5 that varying $\mu^{*}$ changes both $\mu$ and $\sigma$ even if $\sigma^{*}$ is held constant) are all affected by the two circulation indices. However, in the interests of simplicity, we allowed all four parameters to vary in the fully conditioned models.

\section{Induced model for monthly precipitation}

\section{I. Properties of the induced model}

We have seen in sections 6 and 7 the effects of largescale atmospheric circulation indices of SLP and GWD on the magnitude of the occurrence $(\pi, \rho)$ and intensity $(\mu, \sigma)$ parameters of the daily precipitation models. We are interested in the aggregation of the statistically generated daily precipitation to monthly precipitation using the chain-dependent process (Katz, 1977b). The non-zero daily precipitation amount time series is represented by $X_{1} \ldots X_{N}$, where $N$ is the number of wet days (a random variable) of a total series of $T$ days (a month). Its distribution is determined by the Markovchain model, equations (3) to (5), for the daily occurrence process $J_{t}$. The total monthly precipitation $S_{T}$ (sum of the daily intensities), the mean $\mathrm{E}\left(S_{T}\right)$, and the variance $\operatorname{Var}\left(S_{T}\right)$ for the unconditioned model can be computed (Feller, 1968), from:

$$
\begin{gathered}
S_{T}=X_{1}+X_{2}+\ldots+X_{N} \\
\mathrm{E}\left(S_{T}\right)=T \pi \mu \\
\operatorname{Var}\left(S_{T}\right) \approx T\left\{\pi \sigma^{2}+\pi(1-\pi)[(1+\rho) /(1-\rho)] \mu^{2}\right\}
\end{gathered}
$$

where $\mathrm{E}$ is the expected value.

The mean monthly precipitation computed from equation (9) is similar to that of observed monthly means (Figure 3). However, the monthly variance computed from equation (10), and shown in Tables 2 and 3, poorly estimates the observed values of Figure 3. So while aggregating the daily mean to the monthly mean is acceptable, aggregation of the variance is far from adequate. As the distribution of the individual daily precipitation intensities is positively skewed (as governed by the power transform parameter, ) the distribution of the total monthly precipitation should be to some extent positively skewed. The shape of the monthly distribution can be estimated using simulation algorithms, and is discussed in section 8 .

The effects of conditioning are examined using an induced model based on combining the conditioned models. This induced model for monthly precipitation is a combination of the two chain-dependent processes ( Katz \& Parlange, 1993). The mean and variance of the total monthly precipitation is expressed in terms of the conditional means and variances, given the circulation index $I$, as:

$$
\begin{gathered}
\mathrm{E}\left(S_{T}\right)=\mathrm{E}\left[\mathrm{E}\left(S_{T} \mid I\right)\right] \\
\left.\operatorname{Var}\left(S_{T}\right)=\mathrm{E}\left[\operatorname{Var}\left(S_{T} \mid I\right)\right]+\operatorname{Var}\left[\mathrm{E}\left(S_{T}\right) \mid I\right)\right]
\end{gathered}
$$

The monthly mean estimated from equation (11) is the weighted average of the two conditioned means, and yields a mean similar (not necessarily identical) to the unconditioned mean, and so serves only as a computational check. However, the variance from equation (12), is not a weighted average of two conditioned variances, because of the second term of equation (12). The underestimate of variance in stochastic precipitation modelling is one of its major weaknesses (e.g. Gregory et al., 1993; Katz \& Parlange, 1996b.) and here with a mixed distribution we are able to arrive at an improved estimate of the monthly variance. The induced model for daily/monthly precipitation is treated in more detail in Katz \& Parlange (1996a).

\subsection{Results of the induced monthly model}

The mean monthly precipitation depends on the probability of a wet day $(\pi)$ and on the mean untransformed daily precipitation $(\mu)$. In Table A1, for the SLP model, $\pi$ is more important than $\mu$ for the months of June, August and November and $\mu$ is the more important for the other nine months (as defined by the percentage difference between the $\pi$ at $I=0$ and $I=1$ and $\mu$ at $I=0$ and $I=1$ ). For example for April, if $\pi$ is varied between its two conditional values and $\mu$ is held constant at its unconditional value, substituting into equation (9), yields a range of $28.2 \mathrm{~mm}$ or $35 \%$ of the unconditional mean. However, if $\pi$ is held constant and $\mu$ is varied, the range is $19.3 \mathrm{~mm}$ or $24 \%$ of the unconditional mean. For the GWD model, $\pi$ is more important than $\mu$ except for the months of January, September and December.

The four daily model parameters $\pi, \rho, \mu$ and $\sigma^{2}$ each make important contributions to the variance of monthly precipitation. From Table A1 for the SLP model and Table A2 for the GWD model, we find that the differences for intensity parameters $\mu$ and $\sigma^{2}$ (between $I=0$ and $I=1$ ) are 


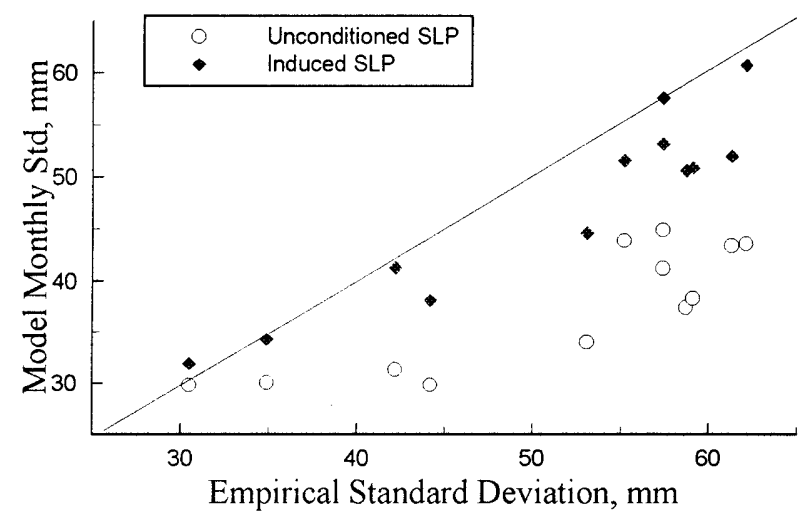

Figure 6. Comparison of the standard deviation for monthly precipitation, for the unconditioned and induced SLP model.

more significant than the associated differences for occurrence parameters. This is determined by comparing the results obtained by substitution into equation (10), by first holding $\pi$ and $\rho$ constant at their unconditional values and allowing $\mu$ and $\sigma^{2}$ to vary between their conditional values and secondly by holding $\mu$ and $\sigma^{2}$ constant at their unconditional values and allowing $\pi$ and $\rho$ to vary between their conditional values.

Table 2 compiles the results of the SLP induced model for the standard deviation for each of the 12 months. It is seen that the standard deviation of the unconditioned model underestimates the observed values by up to $36 \%$ in at least three months. The conditioned models also underestimate the empirical standard deviation, but by values somewhat less than the unconditioned model. The induced model is an improvement with those months that were up to $36 \%$ underestimates, now closer to $15 \%$ underestimates. The standard deviation for the induced model is plotted in Figure 6, and an improvement is seen for all months, with five of the 12 months reproducing the observed standard deviation. This improvement in modelling the standard deviation is similar to the finding of Katz \& Parlange (1993).

Table 3 compiles the results of the GWD induced monthly model for the standard deviation for each of the 12 months. The induced model is only a slight improvement on the estimates of the monthly standard deviation. Those months that were up to $36 \%$ underestimates for the unconditioned model are now about $28 \%$ underestimates using the GWD induced model.

Clearly, with regard to modelling the standard deviation of the monthly total precipitation, the SLP index is a significant improvement over the unconditioned model and better than the GWD model induced model.

\section{Shape and results of the distribution of monthly precipitation}

In addition to the mean and standard deviation of the monthly precipitation, the distribution can also be modelled. The distribution of daily total precipitation is positively skewed (as is monthly precipitation). This monthly distribution can be estimated by simulation. Chain-dependent processes because of their structure are amenable to simulation algorithms. Synthetic sequences, representing time series of daily precipitation amounts, are generated for both conditioned chain-dependent processes $(I=0$ and $I=1)$, and then summed to obtain an artificial monthly total precipitation. The simulation experiment was run 1000 times for each model, producing empirical conditioned distributions of monthly total precipitation given the circulation index $I$.

Figure 7 summarises the result of the SLP simulation experiment for the 12 months, for $I=0$ and $I=1$. The parameters $\left(\pi, \rho, \mu^{*}, \sigma^{*}\right.$ and $p$ ) with values from Table A1 are used in the simulation run, for both $I=0$ and $I=1$. It is of interest to note that the monthly mean of the distributions for $I=0$ (low pressure) and $I=1$ are significantly different for most months as shown in Figure 3. The mean monthly difference is highest at $80 \mathrm{~mm}$ for September and October and lowest at $26 \mathrm{~mm}$ for June and $34 \mathrm{~mm}$ for April. It is also clear from Figure 7 that the shape of the distribution is less positively skewed when $I=0$ (low pressure). Because we only have 54 years (i.e. 54 Januarys ) it is not possible to see this effect from the real data.

Figure 8 shows the result of the GWD simulation experiment for the 12 months, for $I=0$ and $I=1$. The parameters $\left(\pi, \rho, \mu^{*}, \sigma^{*}\right.$ and $\left.p\right)$ with values from Table A2 are used, for both $I=0$ and $I=1$. Like the SLP model, the differences between the mean monthly precipitation are significant but not as significant as with the SLP model. The greatest difference is for September at $66 \mathrm{~mm}$ and the lowest is for June with $0 \mathrm{~mm}$. It is also clear from Figure 8 that the shape of the distribution is less positively skewed when $I=0$ (low pressure). Because we only have 35 years (i.e. 35 Januarys) it is not possible to see this effect from the real data.

\section{Discussion and conclusions}

Long time series of daily precipitation at Valentia, on the south-west coast of Ireland, have been fit with unconditioned and conditioned chain-dependent processes. An occurrence process and an intensity process define the chain-dependent process. Conditioning has been done using two different indices of large-scale atmospheric circulation, namely: monthly sea level pressure (SLP) and monthly geostrophic wind direction (GWD), both at the same site. Using SLP, the mean monthly sea level pressure is first determined for each month, and then the conditioned models are partitioned into two sets: one precipitation data set associated with higher than the mean monthly SLP and the second set associated with low pressure. A similar indexing using geostrophic wind direction is used, 

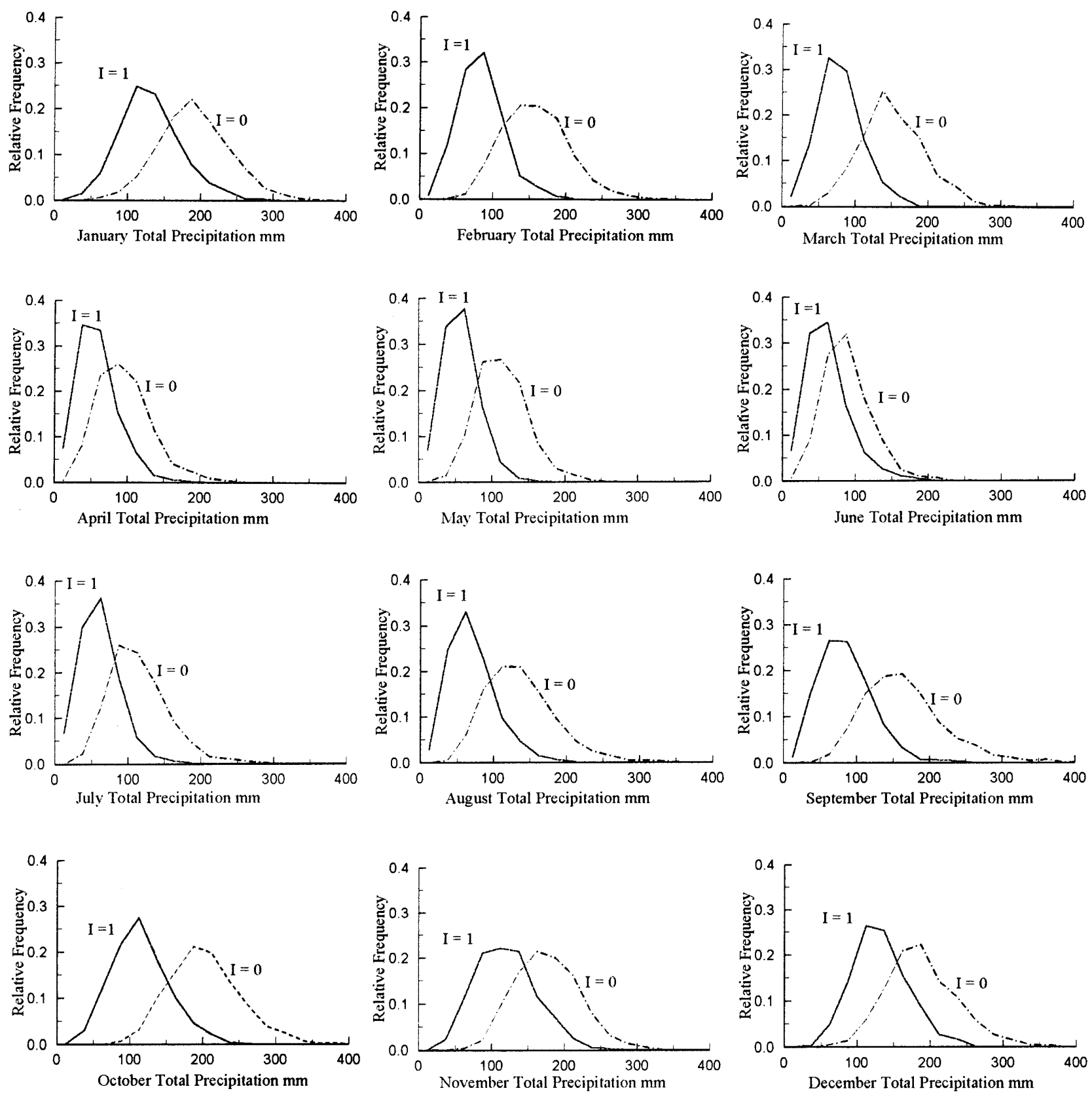

Figure 7. SLP conditioned distributions of monthly total precipitation, for $I=0$, and $I=1$, from simulation of daily time series based on chain-dependent processes.

where the dominant precipitation bearing wind directions are confined to an active storm 'quadrant', analogous to low sea level pressure.

The length of records used for SLP analysis was 54 years and 35 years for the GWD analysis. However, there is almost no difference between the SLP and GWD observed unconditioned monthly means (Figure 3 ) and no difference between the SLP and GWD unconditioned monthly standard deviation, as shown in Tables 2 and 3. There are significant differences (as much as $32 \%$ for October) for the $(I=0)$ conditioned standard deviations, between SLP and GWD. Similarly, there are significant differences (as much as $89 \%$ for September) for the $(I=1)$ conditioned standard deviation between SLP and GWD.
The two conditioned models produce significantly different parameters of the occurrence (probability of a wet day) and intensity process (mean of intensity). Obviously, higher probabilities of wet days and higher mean intensities are associated with the 'low pressure' conditioning. The same holds for the GWD conditioning of the active storm 'quadrant'.

An induced monthly model, composed of combining both conditioned models, produces a variance which is much closer to the observed, more so for the case of SLP conditioning than for the GWD conditioning. The standard deviation for monthly total precipitation using the induced model is an improvement on the unconditioned model. 

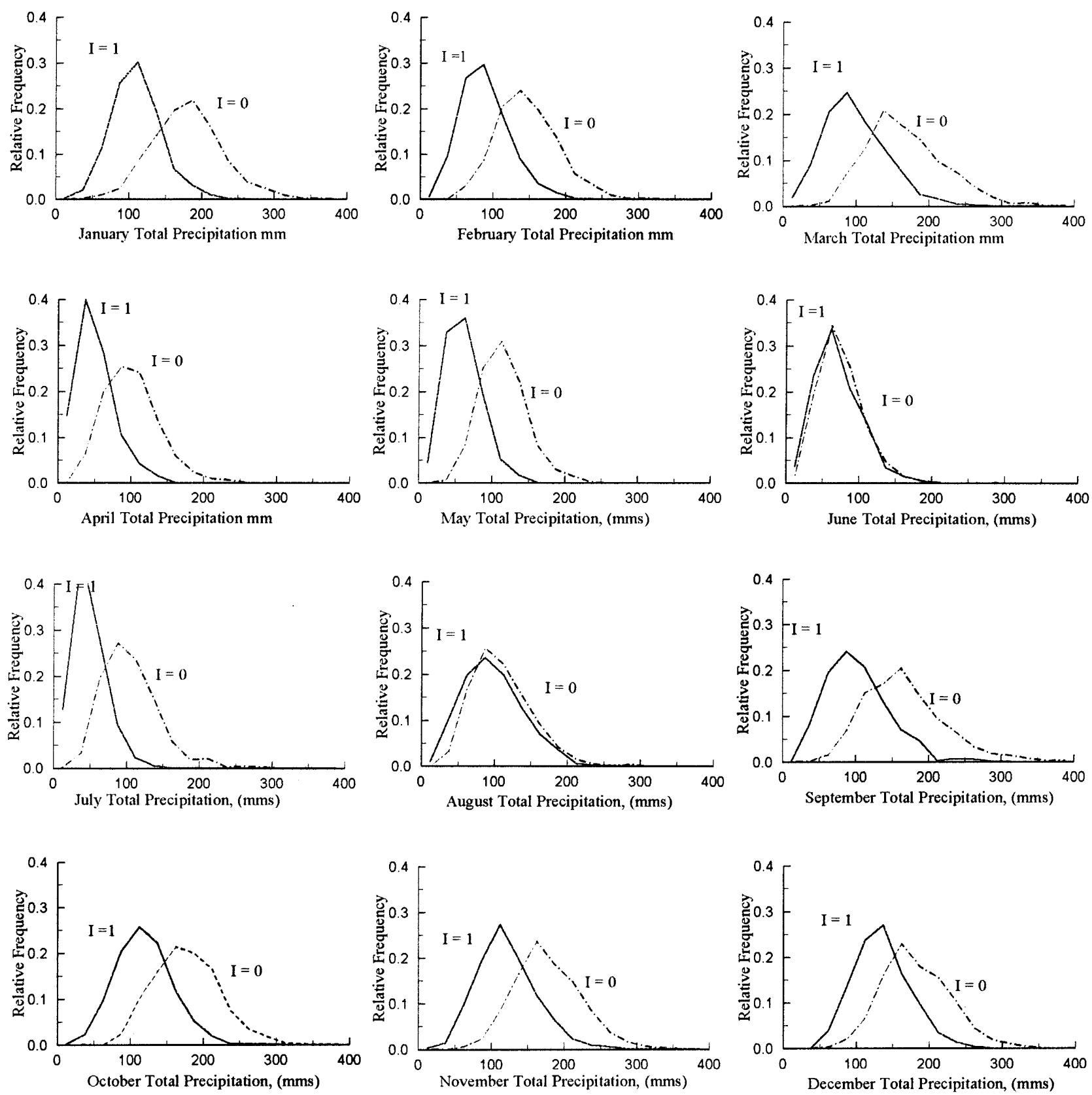

Figure 8. GWD conditioned distributions of montbly total precipitation, for $I=0$, and $I=1$, from simulation of daily time series based on chain-dependent processes.

This monthly indexing of either SLP or GWD has potential to be used in precipitation modelling. The indexing data in terms of monthly SLP can be obtained from GCMs so this technique could be used in simulating monthly precipitation statistics. The latter has application to rainfall/runoff modelling. Since GCMs can provide SLP fields for future climate conditions with increased greenhouse gas concentrations in the atmosphere, the conditional SLP model could therefore have applications in climate change impact assessment.

\section{Acknowledgements}

The authors acknowledge with thanks the Irish
Meteorological Service for the raw data and also the comments of the two anonymous referees that led to substantial improvements of the paper.

\section{Appendix. Parameters of daily precipitation}

This appendix contains Table A1 and Table A2. The estimated parameters in Table A1 are for the unconditional and SLP conditional chain-dependent processes for the time series of daily precipitation amounts for all 12 months of the year. Table A2 shows the corresponding parameters for the GWD case. The data used to plot Figure 5 is contained in Table A1. A similar plot to Figure 5 for the GWD case can be created from Table A2 but is omitted here in the interest of brevity. 
Conditioning precipitation with atmospheric circulation indices

Both tables contain (for the daily model) the parameters of the occurence process (occurrence and persistence) and the intensity process (mean and standard deviation), for the unconditional and two conditional models. Also included are the parameters of the transformed intensity process (exponent $p$, tranformed mean and transformed standard deviation).

Table A1. Parameters of unconditioned and conditioned SLP chain-dependent processes for time series of daily precipitation amounts for all 12 months at Valentia

\begin{tabular}{|c|c|c|c|c|c|c|c|c|}
\hline \multirow[t]{2}{*}{ Month } & \multirow[t]{2}{*}{ Model } & \multicolumn{2}{|c|}{ Occurrence process } & \multicolumn{2}{|c|}{ Intensity process } & \multicolumn{3}{|c|}{ Transformed intensity process } \\
\hline & & $\begin{array}{l}\text { Occurrence } \\
\pi \\
\end{array}$ & $\begin{array}{c}\text { Persistence } \\
\rho \\
\end{array}$ & $\begin{array}{l}\text { Mean } \\
\frac{\mu}{(\mathrm{mm})}\end{array}$ & $\begin{array}{c}\begin{array}{c}\text { Standard } \\
\text { deviation }\end{array} \\
\sigma \\
(\mathrm{mm})\end{array}$ & $\underline{p}$ & $\begin{array}{c}\text { Mean } \\
\mu^{*} \\
\left(\mathrm{~mm}^{\mathrm{p}}\right)\end{array}$ & $\begin{array}{c}\begin{array}{c}\text { Standard } \\
\text { deviation } \\
\sigma^{*}\end{array} \\
\left(\mathrm{~mm}^{\mathrm{p}}\right)\end{array}$ \\
\hline Jan. & $\begin{array}{l}\text { Unc } \\
I=0 \\
I=1\end{array}$ & $\begin{array}{l}0.781 \\
0.842 \\
0.720\end{array}$ & $\begin{array}{l}0.466 \\
0.470 \\
0.438\end{array}$ & $\begin{array}{l}6.74 \\
7.390 \\
5.950\end{array}$ & $\begin{array}{l}7.48 \\
7.52 \\
7.33\end{array}$ & $\begin{array}{l}1 / 4 \\
1 / 4 \\
1 / 4\end{array}$ & $\begin{array}{l}1.422 \\
1.480 \\
1.352\end{array}$ & $\begin{array}{l}0.454 \\
0.429 \\
0.466\end{array}$ \\
\hline Feb. & $\begin{array}{l}\text { Unc } \\
I=0 \\
I=1\end{array}$ & $\begin{array}{l}0.722 \\
0.782 \\
0.666\end{array}$ & $\begin{array}{l}0.421 \\
0.350 \\
0.444\end{array}$ & $\begin{array}{l}5.820 \\
7.030 \\
4.500\end{array}$ & $\begin{array}{l}6.80 \\
7.74 \\
5.54\end{array}$ & $\begin{array}{l}1 / 4 \\
1 / 4 \\
1 / 4\end{array}$ & $\begin{array}{l}1.350 \\
1.445 \\
1.246\end{array}$ & $\begin{array}{l}0.457 \\
0.442 \\
0.451\end{array}$ \\
\hline Mar. & $\begin{array}{l}\text { Unc } \\
I=0 \\
I=1\end{array}$ & $\begin{array}{l}0.673 \\
0.743 \\
0.597\end{array}$ & $\begin{array}{l}0.482 \\
0.427 \\
0.482\end{array}$ & $\begin{array}{l}5.500 \\
6.440 \\
4.260\end{array}$ & $\begin{array}{l}6.49 \\
7.08 \\
5.59\end{array}$ & $\begin{array}{l}1 / 4 \\
1 / 4 \\
1 / 4\end{array}$ & $\begin{array}{l}1.332 \\
1.407 \\
1.235\end{array}$ & $\begin{array}{l}0.450 \\
0.450 \\
0.428\end{array}$ \\
\hline Apr. & $\begin{array}{l}\text { Unc } \\
I=0 \\
I=1\end{array}$ & $\begin{array}{l}0.618 \\
0.680 \\
0.545\end{array}$ & $\begin{array}{l}0.412 \\
0.377 \\
0.428\end{array}$ & $\begin{array}{l}4.310 \\
4.680 \\
3.760\end{array}$ & $\begin{array}{l}5.63 \\
5.95 \\
5.20\end{array}$ & $\begin{array}{l}1 / 8 \\
1 / 8 \\
1 / 8\end{array}$ & $\begin{array}{l}1.095 \\
1.110 \\
1.072\end{array}$ & $\begin{array}{l}0.194 \\
0.196 \\
0.188\end{array}$ \\
\hline May & $\begin{array}{l}\text { Unc } \\
I=0 \\
I=1\end{array}$ & $\begin{array}{l}0.606 \\
0.711 \\
0.522\end{array}$ & $\begin{array}{l}0.441 \\
0.410 \\
0.420\end{array}$ & $\begin{array}{l}4.570 \\
5.300 \\
3.830\end{array}$ & $\begin{array}{l}5.55 \\
6.22 \\
4.89\end{array}$ & $\begin{array}{l}1 / 4 \\
1 / 4 \\
1 / 4\end{array}$ & $\begin{array}{l}1.264 \\
1.326 \\
1.201\end{array}$ & $\begin{array}{l}0.433 \\
0.415 \\
0.436\end{array}$ \\
\hline Jun. & $\begin{array}{l}\text { Unc } \\
I=0 \\
I=1\end{array}$ & $\begin{array}{l}0.628 \\
0.718 \\
0.532\end{array}$ & $\begin{array}{l}0.400 \\
0.276 \\
0.427\end{array}$ & $\begin{array}{l}4.100 \\
4.150 \\
3.980\end{array}$ & $\begin{array}{l}5.71 \\
5.69 \\
5.73\end{array}$ & $\begin{array}{l}1 / 8 \\
1 / 8 \\
1 / 8\end{array}$ & $\begin{array}{l}1.089 \\
1.092 \\
1.074\end{array}$ & $\begin{array}{l}0.193 \\
0.191 \\
0.197\end{array}$ \\
\hline Jul. & $\begin{array}{l}\text { Unc } \\
I=0 \\
I=1\end{array}$ & $\begin{array}{l}0.665 \\
0.761 \\
0.583\end{array}$ & $\begin{array}{l}0.395 \\
0.303 \\
0.408\end{array}$ & $\begin{array}{l}4.170 \\
4.790 \\
3.540\end{array}$ & $\begin{array}{l}5.43 \\
5.92 \\
4.91\end{array}$ & $\begin{array}{l}1 / 8 \\
1 / 8 \\
1 / 8\end{array}$ & $\begin{array}{l}1.083 \\
1.108 \\
1.055\end{array}$ & $\begin{array}{l}0.201 \\
0.200 \\
0.196\end{array}$ \\
\hline Aug. & $\begin{array}{l}\text { Unc } \\
I=0 \\
I=1 \\
\text { Unc } \\
I=0 \\
I=1\end{array}$ & $\begin{array}{l}0.693 \\
0.798 \\
0.562 \\
0.710 \\
0.797 \\
0.609\end{array}$ & $\begin{array}{l}0.366 \\
0.279 \\
0.355 \\
0.382 \\
0.300 \\
0.377\end{array}$ & $\begin{array}{l}4.880 \\
5.310 \\
4.130 \\
5.920 \\
6.890 \\
4.350\end{array}$ & $\begin{array}{l}6.18 \\
6.66 \\
5.43 \\
7.55 \\
8.79 \\
5.76\end{array}$ & $\begin{array}{l}1 / 8 \\
1 / 8 \\
1 / 8 \\
1 / 8 \\
1 / 8 \\
1 / 8\end{array}$ & $\begin{array}{l}1.108 \\
1.125 \\
1.079 \\
1.134 \\
1.162 \\
1.095\end{array}$ & $\begin{array}{l}0.203 \\
0.202 \\
0.201 \\
0.211 \\
0.210 \\
0.201\end{array}$ \\
\hline Oct. & $\begin{array}{l}\text { Unc } \\
I=0 \\
I=1\end{array}$ & $\begin{array}{l}0.747 \\
0.843 \\
0.682\end{array}$ & $\begin{array}{l}0.394 \\
0.315 \\
0.387\end{array}$ & $\begin{array}{l}6.550 \\
7.750 \\
5.540\end{array}$ & $\begin{array}{l}7.55 \\
8.33 \\
6.84\end{array}$ & $\begin{array}{l}1 / 4 \\
1 / 4 \\
1 / 4\end{array}$ & $\begin{array}{l}1.390 \\
1.477 \\
1.317\end{array}$ & $\begin{array}{l}0.475 \\
0.469 \\
0.466\end{array}$ \\
\hline Nov. & $\begin{array}{l}\text { Unc } \\
I=0 \\
I=1\end{array}$ & $\begin{array}{l}0.770 \\
0.868 \\
0.698\end{array}$ & $\begin{array}{l}0.498 \\
0.433 \\
0.494\end{array}$ & $\begin{array}{l}6.430 \\
6.940 \\
5.900\end{array}$ & $\begin{array}{l}7.43 \\
7.76 \\
7.12\end{array}$ & $\begin{array}{l}1 / 4 \\
1 / 4 \\
1 / 4\end{array}$ & $\begin{array}{l}1.399 \\
1.439 \\
1.360\end{array}$ & $\begin{array}{l}0.449 \\
0.444 \\
0.444\end{array}$ \\
\hline Dec. & $\begin{array}{l}\text { Unc } \\
I=0 \\
I=1\end{array}$ & $\begin{array}{l}0.813 \\
0.852 \\
0.768\end{array}$ & $\begin{array}{l}0.464 \\
0.439 \\
0.467\end{array}$ & $\begin{array}{l}6.420 \\
7.160 \\
5.470\end{array}$ & $\begin{array}{l}7.34 \\
7.71 \\
6.78\end{array}$ & $\begin{array}{l}1 / 4 \\
1 / 4 \\
1 / 4\end{array}$ & $\begin{array}{l}1.395 \\
1.450 \\
1.323\end{array}$ & $\begin{array}{l}0.459 \\
0.457 \\
0.451\end{array}$ \\
\hline
\end{tabular}


G Kiely et al.

Table A2. Parameters of unconditioned and conditioned GWD chain-dependent processes for time series of daily precipitation amounts for all 12 months at Valentia

\begin{tabular}{|c|c|c|c|c|c|c|c|c|}
\hline \multirow[t]{2}{*}{ Month } & \multirow[t]{2}{*}{ Model } & \multicolumn{2}{|c|}{ Occurrence process } & \multicolumn{2}{|c|}{ Intensity process } & \multicolumn{3}{|c|}{ Transformed intensity process } \\
\hline & & $\begin{array}{l}\text { Occurrence } \\
\qquad \pi\end{array}$ & $\begin{array}{c}\text { Persistence } \\
\rho\end{array}$ & $\begin{array}{c}\text { Mean } \\
\begin{array}{c}\mu \\
(\mathrm{mm})\end{array}\end{array}$ & $\begin{array}{c}\text { Standard } \\
\text { deviation } \\
\sigma \\
(\mathrm{mm})\end{array}$ & $\mathrm{p}$ & $\begin{array}{l}\text { Mean } \\
\mu^{*} \\
\left(\mathrm{~mm}^{\mathrm{p}}\right)\end{array}$ & $\begin{array}{c}\text { Standard } \\
\text { deviation } \\
\sigma^{*} \\
\left(\mathrm{~mm}^{\mathrm{p}}\right)\end{array}$ \\
\hline \multirow[t]{3}{*}{ Jan. } & Unc & 0.788 & 0.447 & 6.537 & 7.092 & $1 / 4$ & 1.412 & 0.447 \\
\hline & $I=0$ & 0.810 & 0.354 & 6.997 & 7.465 & $1 / 4$ & 1.450 & 0.453 \\
\hline & $I=1$ & 0.765 & 0.538 & 6.035 & 6.650 & $1 / 4$ & 1.341 & 0.408 \\
\hline \multirow[t]{3}{*}{ Feb. } & Unc & 0.703 & 0.431 & 5.858 & 6.818 & $1 / 4$ & 1.351 & 0.461 \\
\hline & $I=0$ & 0.792 & 0.349 & 6.582 & 7.080 & $1 / 4$ & 1.409 & 0.453 \\
\hline & $I=1$ & 0.619 & 0.447 & 5.087 & 6.410 & $1 / 4$ & 1.287 & 0.456 \\
\hline \multirow[t]{3}{*}{ Mar. } & Unc & 0.671 & 0.510 & 5.979 & 6.922 & $1 / 8$ & 1.154 & 0.197 \\
\hline & $I=0$ & 0.765 & 0.335 & 6.543 & 7.047 & $1 / 8$ & 1.174 & 0.195 \\
\hline & $I=1$ & 0.582 & 0.568 & 5.284 & 6.738 & $1 / 8$ & 1.128 & 0.195 \\
\hline \multirow[t]{3}{*}{ Apr. } & Unc & 0.580 & 0.411 & 4.437 & 5.775 & $1 / 8$ & 1.097 & 0.196 \\
\hline & $I=0$ & 0.683 & 0.378 & 4.883 & 6.047 & $1 / 8$ & 1.119 & 0.190 \\
\hline & $I=1$ & 0.471 & 0.377 & 3.772 & 5.416 & $1 / 8$ & 1.063 & 0.203 \\
\hline \multirow[t]{3}{*}{ May } & Unc & 0.639 & 0.395 & 4.577 & 5.205 & $1 / 4$ & 1.282 & 0.413 \\
\hline & $I=0$ & 0.740 & 0.246 & 5.146 & 5.520 & $1 / 4$ & 1.336 & 0.406 \\
\hline & $I=1$ & 0.553 & 0.410 & 3.840 & 4.812 & $1 / 4$ & 1.211 & 0.405 \\
\hline \multirow[t]{3}{*}{ Jun. } & Unc & 0.617 & 0.402 & 4.111 & 5.646 & $1 / 8$ & 1.087 & 0.193 \\
\hline & $I=0$ & 0.641 & 0.399 & 4.052 & 5.204 & $1 / 8$ & 1.089 & 0.194 \\
\hline & $I=1$ & 0.592 & 0.383 & 4.259 & 6.109 & $1 / 8$ & 1.086 & 0.192 \\
\hline \multirow[t]{3}{*}{ Jul. } & Unc & 0.641 & 0.386 & 4.098 & 5.398 & $1 / 8$ & 1.079 & 0.198 \\
\hline & $I=0$ & 0.749 & 0.376 & 4.671 & 6.268 & $1 / 8$ & 1.101 & 0.201 \\
\hline & $I=1$ & 0.528 & 0.335 & 3.200 & 4.296 & $1 / 8$ & 1.046 & 0.189 \\
\hline \multirow[t]{3}{*}{ Aug. } & Unc & 0.665 & 0.398 & 5.052 & 6.470 & $1 / 8$ & 1.114 & 0.202 \\
\hline & $I=0$ & 0.748 & 0.259 & 4.740 & 5.746 & $1 / 8$ & 1.109 & 0.197 \\
\hline & $I=1$ & 0.586 & 0.457 & 5.446 & 7.177 & $1 / 8$ & 1.121 & 0.200 \\
\hline \multirow[t]{3}{*}{ Sep. } & Unc & 0.700 & 0.385 & 6.049 & 7.353 & $1 / 8$ & 1.143 & 0.207 \\
\hline & $I=0$ & 0.779 & 0.378 & 6.969 & 8.436 & $1 / 8$ & 1.155 & 0.209 \\
\hline & $I=1$ & 0.633 & 0.379 & 5.131 & 6.238 & $1 / 8$ & 1.113 & 0.197 \\
\hline \multirow[t]{3}{*}{ Oct. } & Unc & 0.742 & 0.387 & 6.289 & 7.237 & $1 / 4$ & 1.377 & 0.468 \\
\hline & $I=0$ & 0.823 & 0.249 & 6.746 & 7.479 & $1 / 4$ & 1.410 & 0.467 \\
\hline & $I=1$ & 0.674 & 0.379 & 5.858 & 7.010 & $1 / 4$ & 1.345 & 0.460 \\
\hline \multirow[t]{3}{*}{ Nov. } & Unc & 0.771 & 0.507 & 6.598 & 7.772 & $1 / 4$ & 1.409 & 0.450 \\
\hline & $I=0$ & 0.854 & 0.464 & 7.017 & 8.257 & $1 / 4$ & 1.435 & 0.452 \\
\hline & $I=1$ & 0.684 & 0.489 & 6.055 & 7.211 & $1 / 4$ & 1.373 & 0.445 \\
\hline \multirow[t]{3}{*}{ Dec. } & Unc & 0.828 & 0.392 & 6.386 & 7.441 & $1 / 4$ & 1.389 & 0.459 \\
\hline & $I=0$ & 0.866 & 0.355 & 6.838 & 7.355 & $1 / 4$ & 1.425 & 0.459 \\
\hline & $I=1$ & 0.782 & 0.436 & 5.772 & 7.525 & $1 / 4$ & 1.341 & 0.455 \\
\hline
\end{tabular}




\section{References}

Bardossy, A. \& Caspary, H. J. (1990). Detection of climate change in Europe by analyzing European atmospheric circulation patterns from 1881-1989. Theor. Appl. Climatol. 42: 153-167.

Bardossy, A. \& Plate, E. J. (1992). Space-time model for daily rainfall rising atmospheric circulation patterns. Water Resources Res., 28: 1247-1259.

Cayan, D. R. \& Peterson, D. H. (1989). The influence of North-Pacific atmospheric circulation on streamflow in the West. In Aspects of climate variability in the Pacific and Western Americas, Geophys. Monogr. Ser., Vol. 55, edited by D.H.Peterson, pp. 375-397, AGU, Washington, DC.

Feller W. (1968). An introduction to probability theory and its applications, Vol.1, 3rd edn., 509 pp. John Wiley, New York.

Gregory, J. M., Wigley, T. M. L. \& Jones, P. D. (1993). Application of Markov models to area-averaged daily precipitation series and interannual variability in seasonal totals. Climate Dynam., 8: 299-310.

Hinkley, D. V. (1976). On quick choice of power transform. Appl. Stat., 26: 67-69.

Houghton, J. G. \& O’Cinneide, M. S. (1976). Synoptic origin of Irish precipitation 1970-1971. Weather, 31: 11-25.

Hughes, J. P., Lettenmaier, D. P. \& Guttorp, P. (1993). A stochastic approach for assessing the effect of changes in synoptic circulation patterns on gauge precipitation. Water Resources Res., 29: 3303-3315.

Hurrell, J. W. (1995). Decadel trends in the North-Atlantic oscillation-regional temperatures and precipitation. Science, 269: 676-679.

Katz, R. (1977a). Precipitation as a chain-dependent process. J. Meteorol., 16: 671-676.

Katz, R. (1977b). An application of a chain-dependent process to meteorology. J. Appl. Probability, 14: 598-603.

Katz, R. \& Garrido, J. (1985). Sensitivity analysis of extreme precipitation events. Int. J. Climatol., 14: 985-989.

Katz, R. W. \& Parlange, M. B. (1993). Effects of an index of atmospheric circulation on stochastic properties of precipitation. Water Resources Res., 29: 2335-2344.
Katz, R. W. \& Parlange, M. B. (1995). Generalizations of chain-dependent processes: Application to hourly precipitation. Water Resources Res., 31: 1331-1341.

Katz, R. W. \& Parlange, M. B. (1996a). Mixture of stochastic processes: applications to statistical downscaling. Climate Res., 7: 185-193.

Katz, R. W. \& Parlange, M. B. (1996b). Overdispersion phenomenon in stochastic modelling of daily precipitation. In Proceedings of 13th Conference on Probability and Statistics in Atmospheric Sciences, San Francisco, pp. 291-294.

Kiely, G., Albertson, J. D. \& Parlange, M. B. (1998). Recent trends in diurnal variation of precipitation at Valentia on the South West coast of Ireland. Submitted to J. Hydrology.

Lamb, H. H. (1950). Types and spells of weather around the year in the British Isles: annual trends, seasonal structure in the year, singularity. Q. J. R. Meteorol. Soc., 76: 393-438.

Sweeney, J. C. \& O’Hare, G. P. (1992). Geographical variations in precipitation yields and circulation types in Britain and Ireland. Trans. Inst. Br. Geogr., NS 17: 448-463.

Sweeney, J. C. (1985). The changing synoptic origins of Irish precipitation. Trans. Inst. Br. Geogr., NS 10: 467-480.

Waymire, E. \& Gupta, V. K. (1981). The mathematical structure of rainfall representations. 1. A review of the stochastic rainfall models. Water Resources Res., 17: 1261-1272.

Weare, B. C. \& Hoeschele, M. A. (1983). Specification of monthly precipitation in the Western United States from monthly mean circulation. J. Climatol. Appl. Meteorol., 22: 1000-1007.

Wilson, L. L. \& Lettenmaier, D. P. (1992). A hierarchical stochastic model of large scale atmospheric circulation patterns and multiple station daily precipitation. $J$. Geophysical Res., 97: 2791-2809.

Woolhiser, D. A., Keefer, T. O. \& Redmond, K. T. (1993). Southern oscillation effects on daily precipitation in the South-Western United States. Water Resources Res., 29: 1287-1295. 